\title{
Transduction of Penicillin Resistance together with Ability to Ferment Mannitol and Ribose in Staphylococcus epidermidis
}

\author{
By KRYSTYNA NAZAR AND P. B. HECZKO \\ Institute of Microbiology, Medical Academy, Krakow, Poland \\ AND G. PULVERER \\ Institute of Hygiene, University of Cologne, Cologne, West Germany
}

(Received 3I August 1976; revised I5 November 1976)

\section{INTRODUCTION}

Staphylococcus epidermidis strains living on the human body are potential reservoirs of plasmids which can be transferred to Staphylococcus aureus in vivo (Lacey, 1975). Although the existence of plasmid-linked resistance to tetracycline, chloramphenicol and neomycin in S. epidermidis strains has been documented (Minshew \& Rosenblum, 1972; Rosendorf \& Kayser, 1974), and genes controlling the resistance to several antibiotics have been transduced intra- and interspecifically (Yu \& Baldwin, 197I), all attempts to transfer penicillinase genes in S. epidermidis have failed (Yu \& Baldwin, 1971; Minshew \& Rosenblum, 1972; Rosendorf \& Kayser, 1974). Experiments with atypical multiresistant hospital strains of S. epidermidis (BV) indicated that the genes responsible for penicillinase synthesis are located on a plasmid which also controls aerobic fermentation of mannitol and ribose (Schaefler, 1972).

This communication describes transfer of genes for penicillinase synthesis together with those for some biochemical characteristics between $S$. epidermidis strains using recently isolated S. epidermidis bacteriophages (Pulverer, Pillich \& Klein, 1975).

\section{METHODS}

Organisms. Penicillin-resistant $S$. epidermidis strains (IPOI to IP83), isolated from bacteriaemia cases in children and characterized previously (Heczko, Kasprowicz \& Wanicka, 1972), and polyvalent S. epidermidis bacteriophages Ph9, Phro and U14 (Pulverer et al., r975) were used.

Determination of drug resistance. Resistance to penicillin $\left(25 \mu \mathrm{g} \mathrm{ml}^{-1}\right)$, erythromycin ( $12.5 \mu \mathrm{g} \mathrm{ml}^{-1}$ ) and novobiocin (12.5 $\mu \mathrm{g} \mathrm{ml}^{-1}$ ) was detected by an agar dilution test (Grove \& Randall, 1955).

Biochemical tests. Anaerobic fermentation of glucose, aerobic fermentation of mannitol, maltose and ribose, and production of phosphatase, urease, nuclease and acetoin were detected as described by Heczko, Jeljaszewicz \& Pulverer (1974).

Elimination of penicillin resistance. Penicillin-susceptible, penicillinase-negative variants were obtained by treatment of test strains with ethidium bromide, rifampicin or sodium dodecyl sulphate (Kayser, Wüst \& Corrodi, 1972). All strains were screened for loss of ability to produce penicillinase using the starch iodide method of Perret (1954).

Transduction procedure. Bacteriophages were propagated on the donor strains using the soft agar method (Swanstrom \& Adams, I95I). Phage lysates were filtered through mem- 
Table I. Changes in characteristics associated with loss of ability to produce penicillinase

\begin{tabular}{|c|c|c|c|c|c|c|c|c|c|c|c|}
\hline \multicolumn{8}{|c|}{ Characteristics* of penicillinase-negative variants } & \multicolumn{3}{|c|}{$\begin{array}{l}\text { No. of variants } \\
\text { after treatment with: } \dagger\end{array}$} & \multirow[b]{2}{*}{ Total } \\
\hline Nov & Man & Rib & Mal & Pho & Ace & Nuc & Ure & EB & Rif & SDS & \\
\hline+ & - & + & - & - & - & - & - & 4 & 4 & 5 & 13 \\
\hline+ & + & + & - & - & - & - & - & 2 & 4 & 4 & 10 \\
\hline+ & + & + & - & - & + & - & - & I & 3 & 0 & 4 \\
\hline- & + & + & - & + & + & - & - & I & I & I & 3 \\
\hline- & - & + & + & - & - & - & + & 2 & 0 & 0 & 2 \\
\hline- & - & + & - & - & + & - & - & I & 0 & I & 2 \\
\hline- & + & - & - & - & + & - & + & I & 0 & I & 2 \\
\hline- & - & + & - & - & + & + & - & 0 & I & I & 2 \\
\hline - & - & + & - & - & - & + & + & I & 0 & 0 & I \\
\hline- & - & + & - & - & + & - & - & I & 0 & 0 & $\mathbf{I}$ \\
\hline- & + & + & - & - & - & + & - & I & 0 & 0 & I \\
\hline+ & + & - & - & - & + & - & - & I & 0 & 0 & I \\
\hline- & - & + & - & - & - & - & + & 0 & I & 0 & I \\
\hline- & - & + & - & + & - & - & - & 0 & I & 0 & I \\
\hline- & - & - & - & - & + & + & - & 0 & I & 0 & I \\
\hline+ & - & + & - & + & + & - & - & 0 & 0 & I & I \\
\hline+ & - & - & - & - & + & + & - & 0 & 0 & I & I \\
\hline- & - & - & - & - & - & - & - & 0 & 0 & I & I \\
\hline al 30 & 2I & 42 & 2 & 5 & 18 & 6 & 6 & 16 & 16 & 16 & $4^{8}$ \\
\hline
\end{tabular}

+ , Resistance to novobiocin or positive biochemical reaction; - , sensitivity to novobiocin or negative biochemical reaction.

- Nov, Resistance to novobiocin; Man, Rib, Mal, aerobic fermentation of mannitol, ribose and maltose, respectively; Pho, Ace, Nuc, Ure, production of phosphatase, acetoin, nuclease and urease, respectively.

$\dagger$ EB, ethidium bromide; Rif, rifampicin; SDS, sodium dodecyl sulphate.

brane filters and tested for their sterility by placing $\mathrm{I} \mathrm{ml}$ portions in $\mathrm{Io} \mathrm{ml}$ nutrient broth and incubating for 5 days at $37^{\circ} \mathrm{C}$. Recipient strains were grown overnight on brain heart infusion (BHI) agar and then inoculated into BHI broth and incubated at $37^{\circ} \mathrm{C}$ with shaking until the end of exponential growth. After heating for 2 min at $56^{\circ} \mathrm{C}$ recipient culture was mixed with an equal volume of phage filtrate and incubated with shaking at $37^{\circ} \mathrm{C}$. The phage to bacteria ratio was about I:I. After $30 \mathrm{~min}$ incubation sodium citrate was added to a final concentration of $0 . \mathrm{I} \mathrm{M}$. The suspension was then centrifuged at $4{ }^{\circ} \mathrm{C}$ and washed twice with BHI broth containing $0.1 \mathrm{M}$-sodium citrate. The pellet was resuspended in BHI broth and appropriate dilutions were plated directly on selective BHI agar plates containing benzyl penicillin ( $\left(0.1 \mu \mathrm{g} \mathrm{ml}^{-1}\right)$. In some experiments the phage filtrate was irradiated with ultraviolet light (u.v.) in sterile Petri dishes at a distance of $30 \mathrm{~cm}$ from a Sterisol FI 140-2K lamp for I to 5 min before mixing with recipient bacteria.

\section{RESULTS AND DISCUSSION}

Elimination of penicillinase production by treatment with ethidium bromide, rifampicin or sodium dodecyl sulphate occurred in between $\mathrm{I} / 50$ and I/I000 of the cultures examined, depending on the strain used and curing agent applied. The best results were obtained after treating the bacteria with sodium dodecyl sulphate. Spontaneous loss of penicillinase production occurred in not more than $\mathrm{r} / 10000$ cultures tested under the same experimental conditions.

Loss of penicillinase production was usually associated with changes in some bio- 
chemical properties and in increased tolerance to novobiocin (Table I), while resistance to erythromycin and anaerobic fermentation of glucose was unchanged in all 48 variants. The changes in production of penicillinase remained the same during 20 subcultures of five selected ribose- and mannitol-negative variants. All 100 colonies picked from each of these subcultures remained ribose- and mannitol-negative.

Staphylococcus epidermidis strains IPI6, IPI7 and IP22 were used as donors and their penicillinase-, mannitol- and ribose-negative variants, IPI6E, IPI6R, IPI6S, IPI7E, IPI7R, IP22E, IP22R and IP22S, were used as recipients. Penicillin resistance was transduced from strain IPI 7 to variant IPI 7 R at a very high frequency, about $10^{-2}$, by phage $U_{1} 4$. Other phages gave frequencies of about $\mathrm{I} \times 10^{-5}$ to $5 \times 1 \mathrm{IO}^{-5}$ with the same recipient. No penicillinase-positive transductants were detected in other paired combinations, regardless of the phage used. The abilities to ferment mannitol and ribose were cotransduced since both were found in all 24 penicillinase-positive transductants tested. However, no change was found in other characteristics.

We also tested the effect of u.v. irradiation on the frequency of transduction of penicillinase genes from strain IPI 7 to recipient IPI 7R. After $5 \mathrm{~min}$ irradiation, the frequency was increased $I \cdot 2-$ to $I \cdot 5$-fold.

Thus by using elimination and transduction procedures on freshly isolated $S$. epidermidis strains we were able to confirm Schaefler's (1972) findings that the genes controlling penicillinase synthesis are linked to the genes responsible for aerobic fermentation of mannitol and ribose. Mannitol fermentation, in spite of its genetic instability, is commonly used for the interspecific differentiation of $S$. epidermidis strains (Baird-Parker, 1965; Kloos \& Schleifer, 1975). Although the ability to synthesize penicillinase and to ferment mannitol and ribose can be eliminated by plasmid-curing agents and transduced among $S$. epidermidis strains, it is still an open question whether or not genes responsible for them are chromosomally located. Simultaneous loss of at least three phenotypic characters at comparatively high frequency together with irreversibility of the changes and a small increase in transduction frequency suggest a plasmid location (Novick, 1969; Rubin \& Rosenblum, I971).

A new set of $S$. epidermidis phages of broad activity for both staphylococcal species offers some new possibilities for studying the genetics of staphylococci by intra- and interspecific transduction.

\section{REFERENCES}

BaIrd-Parker, A. C. (I965). Staphylococci and their classification. Annals of New York Academy of Sciences $128,4-19$.

Grove, D. C. \& Randall, W. A. (I955). Assay Methods of Antibiotics. A Laboratory Manual, pp. 190-I9I. New York: Medical Encyclopedia.

Heczko, P. B., Kasprowicz, A. \& Wanicka, A. (1972). Biochemical and toxic properties of pathogenic strains of Staphylococcus epidermidis. Experimental Medicine and Microbiology 24, 81-85.

Heczko, P. B., Jeluaszewicz, J. \& Pulverer, G. (I974). Classification of Micrococcaceae isolated from ctinical sources. Zentralblatt für Bakteriologie, Parasitenkunde, Infektionskrankheiten und Hygiene (Abteilung 1 , Originale) A229, 17 I-177.

KAYSER, F. H., WüsT, J. \& CORRODI, P. (1972). Transduction and elimination of resistance determinants in methicillin-resistant Staphylococcus aureus. Antimicrobial Agents and Chemotherapy 2, 21 7-223.

KLoos, W. E. \& SchleIfER, K. H. (1975). Simplified scheme for routine identification of human Staphylococcus species. Journal of Clinical Microbiology 1, 82-88.

LACEY, R. W. (1975). Antibiotic resistance plasmids of Staphylococcus aureus and their clinical importance. Bacteriological Reviews 39, I-32.

Minshew, B. H. \& Rosenblum, E. D. (1972). Transduction of tetracycline resistance in Staphylococcus epidermidis. Antimicrobial Agents and Chemotherapy I, 508-5II.

Novick, R. P. (1969). Extrachromosomal inheritance in bacteria. Bacteriological Reviews 33, 2 I I-263.

PERRET, C. J. (1954). Iodometric assay of penicillinase. Nature, London 174, IOI2-10I 3.

Pulverer, G., Pillich, J. \& Klein, A. (1975). New bacteriophages of Staphylococcus epidermidis. Journal of Infectious Diseases r32, 524-531. 
Rosendorf, L. L. \& KAyser, F. H. (1974). Transduction and plasmid deoxyribonucleic acid analysis in a multiply antibiotic-resistant strain of Staphylococcus epidermidis. Journal of Bacteriology r20, 679-686.

Rubin, S. J. \& Rosenblum, E. D. (1971). Effect of the recipient strain and ultraviolet irradiation on transduction kinetics of the penicillinase plasmid in Staphylococcus aureus. Journal of Bacteriology ro8, 1 192I 199.

SCHAEFLER, S. (1972). Polyfunctional penicillinase plasmid in Staphylococcus epidermidis: bacteriophage restriction and modification mutants. Journal of Bacteriology 112, 697-706.

Swanstrom, M. \& Adams, M. (I95I). Agar layer method for production of high titre phage stocks. Proceedings of the Society for Experimental Biology and Medicine 78, 372-375.

YU, L. \& BALDWIN, J. N. (197I). Intraspecific transduction in Staphylococcus epidermidis and interspecific transduction between Staphylococcus aureus and Staphylococcus epidermidis. Canadian Journal of Microbiology 17, 767-773. 